\title{
The Role of the London Missionary Society and Church Missionary Society in the Abolition of Oozhiyam (Bonded Labor Service) in Kerala
}

\author{
Ayyappan Balakrishnan \\ balakrishnana1000@gmail.com
}

\section{Abstract}

Bonded labor is the most widespread form of slavery in the world. It is at once the most ancient and most contemporary face of human servitude. In India, 'labor' is more a social category than economics, where the division of labor and laborer is defined according to the caste. The caste system is not a scientific division of labor, which is, after all, necessary for the efficient functioning of any economy. It is an arbitrary, birth-determined hierarchy in which different types of laborers are graded one above the other and subject to a descending scale of civil disabilities that have nothing to do with efficiency or productivity. It is not a division based on choice, as individual sentiment, preference, or even actual skill, have no place in it.

Caste slavery was an oppressive, discriminative, and exploitive system which existed in Kerala from an early medieval period onwards. In the social structure of Kerala, the bonded or forced labor system was an unavoidable factor of slavery. As the system of bonded labor was associated with feudalism, land-based social relations were formed in the state. The oozhiyam or bonded labor system, therefore strictly connected with the caste oriented slavery in Kerala. Under the system of oozhiyam, the economically under-privileged servants were obliged to render bonded services on all days of the week as required by the government officials and the higher castes. The main force behind this system was the coercive authority of the government and the privileged class. Nobody dared to evade the services demanded by the government. Only on the days of the oozhiyam services, the laborers received a minimum quantity of food to keep their body and soul together. This essay mainly focuses on the ameliorating activities of the 
Christian missionaries, such as the London Missionary Society (LMS) and Church Missionary Society (CMS), among the oppressed sections of the society of Kerala. In addition to the social legislations of the government, the intervention of Christian missionaries also helped in the permanent abolition of the system of oozhiyam in Kerala.

Keywords: Caste slavery, oozhiyam, bonded labor, agrestic slaves, oppressed, Dalits, Christianity, religious conversion

\section{Introduction}

A division of labor is a given, as it had crystallized into the caste system in India in general, and particularly in Kerala. Therefore, it logically looks as if the solution for the caste system is to transform the division of labor that created the problem. Marx writes in his book, The poverty of philosophy (Marx [1847] 1955), which is a critique of Proudhon's book with the same title (Proudhon [1847] 2015): 'Under the patriarchal system, under the caste system, under the feudal and corporative system, there was division of labour in the whole of society according to fixed rules' (Marx [1847] 1955:118; cf. Heller 1969:8). Based on Marx's observations, it is to be understood that the division of the labor of the past forms the basis for the caste question. Various kinds of labor are necessary for human beings to live. While different kinds of labor emerge and continue, some other divisions would emerge among them. Keeping aside the question how a given division of labor transformed subsequently, the initial basis would be the existence of different kinds of labor.

Labor relations and processes of economic differentiation are considered the mainstay of the caste hierarchy for India and its perpetuation (Jeffrey 1994:2). Though there are no laws that defend the caste distinctions, all the social conditions are such that they keep the castes intact. Forced and bonded labor is imposed on certain castes in the form of hereditary occupations. This form of bondage is carried on for generations by members of the same occupational caste.

The structure of the society of Kerala during the medieval period was purely built on the pillars of castes. Castes played an important role in the social articulation and political mobilization of Kerala. It therefore gave 
recognition to the division of labor and also the forced labor system. No society was so complex or rigidly controlled as the castes. The entire society of Kerala was rigidly stratified on the basis of castes (Balakrishnan 2016: 122). The orthodox Brahminical principles such as purity and pollution determined the social hierarchy of Kerala. In such a complicated social scenario, different forms of social inequalities and economic exploitations prevailed, including untouchability, unapproachability, invisibility, and slavery.

Legally, 'the bonded labour system' (Greenidge 1958:21) is defined as a force, not only by physical or legal elements, but by the deprivation of alternative choices, economic situations, and a derived compulsion to choose a separate course of action, like providing underpaid or unpaid labor. It created a new type of long-term understanding and relation between the employer and employee, based on caste related functions. In its most essential form, bonded labor involves the extension of credit by the oppressor castes to members of the oppressed castes at extortionate rates of initial and penal interest, calculated to keep the latter in a state of perpetual debt that has to be perpetually repaid in the form of unpaid labor services (Siddharth 2014:3). In Kerala, the most degrading forms of caste-based oppressive systems such as the bonded labor system or oozhiyam services were prevalent in the society. All this wretchedness was imposed to an unwarrantable degree upon the lowest sections of the society (Mateer 1991a:293). The low castes accepted these socio-economic burdens without any hesitation because they believed that it was their inevitable fate to render free services to the higher castes and the temples (Ramachandran 1976:521).

\section{Oozhiam (Bonded Labor System)}

The meaning of the term oozhiyam is 'labor without any remuneration', which was a type of compulsory labor. Therefore, the oozhiyam service was an exploitive institution which totally neglected the rights of the low caste oozhiyam servants of Kerala (Ramachandran 1976:521). Among the most oppressive institutions, oozhiyam occupied a system of harassment in the society. The oozhiyam servants were mainly from the lowest sections of the society of Kerala, such as the Ezhavas, Nadars, Parayas, Pulayas, and the hill tribes. 


\section{Various Oozhiyam Services}

There were two kinds of oozhiyam services in Kerala. The servants of oozhiyam were forced to perform manual services like carrying loads in connection with the government, and building roads, bridges, canals, and thatching sheds for public purposes. They also made certain arrangements with the royal tours and were used to carry the luggage of the people of the royal palace. The rowing of the pallitevaram (a royal boat) was another personal service rendered by the oozhiyam servants. Second, the oozhiyam servants were used to forcibly supply provisions and vegetables to the uttupuras (free feeding houses of the Brahmins) and the palaces. All the services were rendered without remuneration. Therefore, the higher castes freely utilized the labor capacity of the oozhiyam servants and exploited them in many ways (Ramachandran 1976:522).

Slave labor was an inevitable service in the orthodox land tenure system in the medieval social structure of Kerala. The landowners had a number of agrestic slaves for the cultivation of their paddy fields. Besides the agrestic slaves, the state also had thousands of government slaves for the public services of the state (Mateer 1991b:31-32). The slaves were the permanent possession of the landlords and they were permanently attached to the land for cultivation (Dubois 1897:23). The slave owners enjoyed vast and varied rights over their private slaves. They committed untold cruelties against their peasants and slaves, even infringing on the sanctity of their family relationships and sexually abusing the women of the slave castes as a matter of right. The most important among them was the personal gratuitous services or oozhiyam, which were the most persistent source of grievance that fell primarily on the low castes (Jeffrey 1994:51).

The oozhiyam servants forcibly carried money loads from different proverties (villages) to the state exchequer. The bonded servants also carried palanquins of the rulers - Namboothiri Brahmins - and the devadasis (dancing girls of the temples). Namboothiri guests such as the vadyars and vaidikans (priests and physicians belonging to the Brahmin community) were carried by the oozhiyam servants to the Sri Padmanabha Swami temple at Trivandrum in Kerala. These servants performed unending free services at temple festivals and palace ceremonies. Therefore, the oozhiya-viruthikkar suffered because of all these obligations and was reduced to poverty (Ramachandran 1976:522). 
These lowest sections of the society were also used to dig the ground, manure it, transplant the young rice, cull the weeds, repair the banks, and perform in the paddy fields (Varghese 1986:407). The oozhiyam servants also had to ensure a constant supply of coconut leaves for state elephants and grass for the horses. They had to carry residents, transport cadjans (palm leaves) from the landing places to bankshalls (headquarters), monitor elephant traps in the distant jungles, etc.

The bonded laborers formed an important social group in Kerala. According to the first Census Report of 1820, 9,974 individuals out of the total population of the state of 906,587 were slaves (Ward \& Conner 1994:28-29). In 1836, there were 126,863 soil slaves in Kerala. The Resident's Letter to the Dewan (administrative head) of Travancore in $1849 \mathrm{CE}$ testifies that there were 130,000 Sirkar (government) slaves in Kerala (Kusuman 1973:23).

\section{Socio-Economic Conditions of the Oozhiyam Laborers}

The living conditions of the oozhiyam servants in Kerala were even more deplorable. As a segregated group, they were totally excluded from the mainstream of the civic life of the society (Ramachandran 1976:525). The European missionary, Abbe Dubois who visited Kerala between 1792 and 1823 for missionary activities, explained the miserable condition of the slaves, whom he called 'pariahs'. He compared their social conditions with the serfs of France and other parts of Northern Europe (Dubois 1897:23). He also added that it was the worst form of bondage system in Kerala.

The oozhiyam servants were not permitted to build houses with tiled roofs in Kerala. The tiled houses were attacked and destroyed by the high caste Hindus. They made their huts with mud, sticks, reeds, and leaves, close to the marshes and swamps in the middle of the paddy fields. These mud houses did not have any proper doors or ventilations and it was just like small baskets. In addition to the social discrimination, economically, the poor oozhiyam servants were exploited by the government and the higher castes. Therefore, the system of caste slavery acted as both a tool of social oppression and economic exploitation (Balakrishnan 2016:212). Hundreds of taxes were imposed upon the oozhiyam servants, as they were the lowest 
section of the society. Everything of the low castes was taxable and the government always squeezed the laborors' earnings (Yesudas 1977:41).

The system of taxation in Kerala during the medieval period was arbitrary, unscientific, and barbarous. Different kinds of taxes were imposed upon the low castes. Talayara (poll tax) and valayara (net tax) were two important taxes that were implemented in Kerala. In 1754, the government imposed poll tax to meet the military expense of the state. The poll tax was collected not only from the people who were alive, but also from the dead. In 1835 , these taxes were abolished by a proclamation issued by the government.

The oozhiyam servants were marginalized from the civic society. Like animals, they were forced to do hard work without expecting anything except poverty, disease, and exploitation. They did not get the recognition of other human beings and this made them the most horrendous face of the caste system in Kerala (Ramachandran 1976:521).

\section{$1^{\text {th }}$ Century - An Overview}

Change is a dynamic process for rejuvenating a social order or reorganizing a society. The process of change can happen only on the basis of modernization. Modernism is a process by which a society is transformed from its early condition to the present one. Modernity is a significant break from the old forms of social life and practices, giving rise to entirely different forms and patterns of life (Sanal Mohan 2015:80). It is believed that the $19^{\text {th }}$ century was a constructive age in the history of the Indian renaissance. New ideologies inspired the people and in the new spirit of critical thinking and rationalism, the Europeans discouraged the very basic social institutions of castes and slavery in the Indian society. The missionaries forced the government to introduce several social legislations for the development of oozhiyam servants in Kerala. The Britishers started several schools for the low castes and large numbers of low caste children were admitted to these schools. Vocational training was provided in these schools. Besides, the European intervention broke the intellectual isolation of India which also acted as an impetus to the socio-religious reform movements in India (Jeffrey 1994:1).

As an agency of socio-political, cultural, and economic transformation, colonialism used several strategies to attain its goal. Education, techno- 
logy, administrative machinery, religious activities, and the colonial economy were the most important tools used by colonialism to overpower the traditional socio-political and economic structures of Kerala (Kawashima 2006:186). The activities of Col Macaulay, Col John Munro, and Charles Mead accelerated the process of social transformation of the state and also gave some expectations to the lowest sections of the society (Kawashima 2006:186). They gave moral support to the agitations of the weaker sections for attaining civil liberties. The attitude of the British towards the oppressed classes was very sympathetic, which resulted in the introduction of several ameliorating activities such as making social legislations and starting schools for the oppressed in the society (Nisar \& Kandasamy 2007:36-37).

The introduction of the London Missionary Society (LMS) and Church Missionary Society (CMS) in Kerala was a great landmark in the history of the social renaissance of Kerala. Their activities also accelerated the social change among the oppressed sections of the society (Kumar 2010:140). The appointment of Col Macaulay as the first British Resident in 1800 was a great impetus to the missionary activities in Kerala. The British Residents like Col Macaulay and Col Munro wholeheartedly supported the missionary activities (Yesudas 1977:376). They took measures to redress the grievances of the low castes of Kerala. The ruler, Rama Varma praised the efforts of the missionaries as a link to civilization, enlightened progress, and a moral regeneration between the West and the East (Hacker 1908:34)

The LMS and CMS missionaries did not only propagate the idea of the gospel but also labored for the emancipation of the slaves. The Christian missionaries' activities gave a crucial spark to the crusade against the social inequalities which prevailed in Kerala (Kumar 2010:140). They started a vigorous campaign against slavery, which was inextricably connected to the caste system. They raised their voices against the illegal social systems such as the castes, slavery, and the system of forced labor (Yesudas 1977:22). The LMS and CMS missionaries openly challenged the oozhiyam services which were an oppressive social system prevailing in the state. They also challenged the caste privileges of the higher castes, the hierarchy of the social structure, and the disabilities of the slave castes (Jeffrey 1994:20). The LMS and CMS missionaries started several educational institutions for the oppressed classes' education. The missionaries believed that it would provide a better opportunity to the low castes for social upliftment. 
The Protestant missionaries of the LMS and CMS sowed the seeds of a new movement among the slave castes of Kerala in the $19^{\text {th }}$ century (Sanal Mohan 2015:1). The missionaries of both these institutions received a warm welcome from the British Residents (Kawashima 2006:55-56). The missionaries were 'evangelical', as they firmly believed in the infallibility of the scriptures and in salvation by faith through the atonement of Christ (Kooiman 1984:1). The missionary activities of the CMS concentrated in the central parts of Kerala whereas the LMS worked in the southern parts (Yesudas 1977:7). The appointment of Col Macaulay as the first British Resident in 1800 was a great impetus to the missionary activities in Kerala.

\section{Activities of the London Missionary Society}

The LMS was formed in 1795 as an inter-domination body for spreading the gospel of Christ. In India, the activities of the LMS started on 5 December 1804. Col Macaulay granted permission for the introduction of Protestant missionary activities in Kerala. The LMS missionaries' activities spread to areas between Kanyakumari in the south and Quilon in the north. The LMS was widely accepted by the locals because in the southern parts of Kerala, low castes, especially the Nadars and Parayas suffered from several social disabilities and burdens from the orthodox feudal society. The LMS activities created a new consciousness among the oppressed classes. They preached against the social discrimination and the oppressive social practices. Their efforts helped to protect the human rights of the low castes and strongly challenged the oppression and exploitation by the higher castes and the authorities. With the help of the missionaries, the low castes realized their age-old social disabilities and discriminations. The missionaries wrote that 'our work is to promote the eternal interest of the people and if we can procure for them some relief from their temporal distress, it will be our delight to do so' (Annual Report of the London Missionary Society 1841:72).

\section{Ringeltaube}

William Ringeltaube, the first missionary was a Prussian who was invited by Col Macaulay to work in Kerala (Yesudas 1980:27). The arrival of Ringeltaube on 25 April 1806 gave an impetus to the acceleration of the Protestant missionary activities in Kerala. He started his missionary activities in Kerala 
(Agur 1990:40). He wrote that 'our society is indebted to Col Macaulay, without whose determination and fearless interposition, any of the missionnaries would have been able to set a foot in this country' (Agur 1990:40-41).

Ringeltaube was the first LMS missionary who redeemed several slaves from their bondage and was always mindful of the poor. He arrived at Mylady and received permission from the government to build a church there. This first Protestant Church in Kerala was built in 1809. Ringeltaube started his campaign among the natives, particularly among the Nadars because the Nadars were the real victims of suppression and inhuman cruelty from the higher castes and the government (Ponnu 2000:35). Large number of low castes joined the evangelical activities of Christianity. They belonged to different sections of artisans, small traders, and schoolteachers who carried their class sympathies with them (Kooiman 1984:35). Ringeltaube started several schools for the oppressed classes. During this time, the Christian churches acted as schools and the catechists as teachers. He used two important tools - education and Christianity - for the emancipation of the oppressed classes from their age-old sufferings. In these institutions, languages and vocational courses were taught.

\section{Rev Charles Mead}

After the death of Ringeltaube, Rev Charles Mead arrived in Kerala in 1817 and continued the missionary activities of the LMS. He also encouraged the education of slave women of the state. For this purpose, he started several schools for the oppressed classes. Mead believed that education could disseminate truth, overturn errors, and uplift the downtrodden sections of the society. He also started several technical training centers for women (Johnson 2008:129). For the development of the education of the oppressed classes, under his leadership, the missionaries started several schools in villages with teachers who were appointed in these schools. Hundreds of low caste children were admitted to these schools.

In the educational activities of Mead, Johanna Horyst helped him to take off and implement the scheme of establishing schools or seminaries for boy students at Nagercoil. Mead married Horyst in 1819. She became the first missionary woman in Kerala and took the first step for offering education to the girls in Kerala. She also started boarding schools and orphanages. She opened a boarding house attached to the seminary, where a few girl students 
were admitted during their studies. It was the first systematic attempt at women's education in Kerala (Pillai 1996:692). They also offered free food and clothing to the students. In 1818, Mead was appointed as the judge in Nagercoil, where he established the center of missionary activities.

The LMS missionaries decided to start vocational courses for the girl students in the schools, like lace making, embroidery, crotchet, and spinning. The missionaries set up schools in different parts of the state, like in Santhapuram, Parasala, Nedumangad, and Marthandam. Special Sunday schools were also opened in different parts of the state to educate children of the oppressed classes.

\section{Activities of the Church Missionary Society (CMS)}

The activities of the CMS brought a radical change in the social structure of Kerala (Agur 1990:573), as it shook the traditional static society of Kerala and converted it into a progressive one. The CMS concentrated their activities mainly in the central and northern parts of Kerala. They undertook a tendentious task of ameliorating the slaves in Kerala from their age-old sufferings. For this purpose, they used the two instruments - education and conversion - very effectively. The educational activities of the CMS played an important role in the social renaissance of the oppressed classes in Kerala. In 1816, the CMS missionaries founded a college at Kottayam.

\section{CMS Missionaries}

Thomas Norton was the pioneer among the CMS missionaries to promote education to the oppressed and slave castes in Kerala. He started his missionary activities in 1819. In 1835, he started several schools for the slaves which were called pands. Norton admitted students of all communities, irrespective of their caste into his schools.

The CMS started several schools for the oppressed classes in different parts of Kerala, like Mavelikkara, Tiruvalla, Mallapalli, Mundakkayam, and Melukavu. Henry Baker was another CMS missionary who started a slave school at Kottayam. He also permitted the students of the oppressed class into his school. Another attempt was made by Joseph Fenn, also a CMS missionary, who opened a school at Munro Island in 1835. The students from the slave castes joined this school in large numbers. The CMS 
also started several girls' schools, which acted as an efficient instrument for the social upliftment of the low castes.

In 1839, Joseph Peet, a CMS missionary built churches and schools in different parts of Kerala, like Mavelikkara, Poovathur, Kodukulanji, Krishnapuram, and Kattanam. Later, Mavelikkara became an important center of Christianity and English education. Under the leadership of Hawksworth, a separate mission was formed at Tiruvalla in the Pathanamthitta district, which also contributed several educational activities to the oppressed classes in the state. In Mallappally, a place close to the CMS missionaries, the gospel of Christ was preached in such a way that it shook the foundation of the pernicious caste system (Agur 1990:574). They raised their voices against the social inequalities such as slavery, untouchability, pollution, and the forced labor system.

\section{Missionaries and the Abolition of Oozhiyam Services}

The activities of the LMS and CMS missionaries helped to change the socioeconomic backwardness of the lowest sections of the society of Kerala. The missionaries relentlessly worked for the emancipation of these bonded laborers. They were the agents of colonial modernity and the real agents for spreading a Western education of the state. Their education created fresh avenues and spaces among the illiterate, downtrodden sections of the society. Western education and the new liberal ideas were primarily responsible for the social transformation of the oppressed classes in Kerala. During this time, large numbers of low caste people were converted to the Christian religion. They were converted because they believed that it would help them to liberate themselves from slavery and the caste disabilities. These conversions created a shock to the caste Hindus as they observed the activities of the missionaries with suspicious eyes.

After the arrival of the Christian missionaries, the process of the emancipation of oozhiyam servants was started. The missionaries performed a laudable task to educate the slaves and create a new consciousness among the slave castes about their rights and privileges. The crusading spirit of the missionaries for the eradication of slavery and forced labor gave a positive signal to the authorities to introduce certain ameliorating measures to the slaves. In 1789, Lord Cornwallis issued an order against the slave trade in 
India. The Madras government also issued a proclamation which condemned the actions of the slave traffickers. However, none of these proclamations gave a final solution to the basic problems of the slaves in Kerala. In 1812, Col Munro issued a proclamation which prohibited the existing slave trade in the state.

The first concrete effort of the Christian missionaries for the abolition of slavery in Kerala was the Slavery Abolishing Act of 1843. General Cullen, the British Resident took a keen interest to abolish slavery. The missionaries demanded to pass a law in this concern, similar to the law passed by the government of Bengal (Kusuman 1973:45). The Christian missionaries frequently requested the Governor of Madras to immediately intervene in the problems faced by the lowest sections of the society. After an enquiry, the government of Madras demanded the ruler to remove all impediments faced by the low castes (Johnson 2008:134). During April 1850, the government of Madras passed the Caste Disabilities Removal Act. This Act declared that a change of religion will not deprive a person of their right to their property. It also ensured the right of inheritance (Johnson 2008:134). Therefore, the activities of the Christian missionaries put forward the idea of equality and freedom of human beings. Nagam Aiya opines that 'it is a glory reserved to this century of human progress, the epoch of the happy commingles of the civilization of the West with that of the East' (Nagam Aiya 1891:472).

In 1835, the slaves of the Munro Island were liberated. It was the first charter of freedom to the slaves in Kerala. Under the leadership of both the LMS and CMS, a joint petition was submitted to the ruler on March 19, 1847. The petition was signed by 12 missionaries (four from the CMS and eight from the LMS) where they pleaded for the abolition of slavery and the emancipation of the sirkar slaves (Jeffrey 1994:40). In 1848, the missionaries again submitted a petition, which pointed out that the legal recognition of slavery in British India had been withdrawn by Act V of 1843 (Jeffrey 1994:40).

In 1849, General Cullen prepared a memorandum in which he concluded that slaves in Kerala were generally degraded and lived in a more miserable condition than in any other country. He also suggested that the children of the sirkar slaves should be free, and laws should be framed for the protection of slave welfare (Jeffrey 1994:40). During this time, the government granted certain concessions to the slaves. Bowing to the frequent 
pressure of the Christian missionaries, a Royal Proclamation was issued on September 15, 1853, which emancipated the children of the sirkar slaves who were born after 1853 . However, this proclamation did not produce any fruitful result because it liberated only 6,000 children of the sirkar slaves out of the 130,000 slaves in the state. Besides, the second clause of the proclamation insisted that the emancipation could not liberate a low born person from the features of their caste and their untouchability (Jeffrey 1994:40).

The missionaries were disappointed with the 1853 proclamation because it only liberated a very small percentage of the enslaved. The missionaries continuously pleaded for the complete eradication of slavery. For this purpose, they sought public opinion through magazines and periodicals. In 1854, the CMS magazine published the pathetic conditions of the slaves (Varghese 1970:423-424). The frequent demand of the missionaries finally compelled the government to issue a proclamation during April 1855, which totally abolished slavery in the state. This proclamation also abolished the agrestic slavery and a number of feudal levies that were imposed upon the low castes (Nair 1998:18).

The Christian missionaries pleaded for the right of inheritance of the converted Christians as they brought it to the notice of the government. In 1815 , another proclamation was issued, which granted permission to the Ezhavas and Nadarsthat who were converted to Christianity, to inherit property. The Christian missionaries continued their task. The social conditions of the women of the slave castes were deplorable. They strongly pleaded for a social life for the women because the majority of them were miserable and uneducated. The women were not permitted to cover the upper parts of their bodies. After a series of struggles, the government permitted the female converts of the low castes to cover their breasts. Besides, the missionaries offered employment to the oozhiyam servants to improve their social and economic conditions.

\section{Conclusion}

The efforts of the missionaries were unique for the abolition of slavery and bonded labor system in Kerala. It was their drive and initiative, which shook the conscience of all; it was their enthusiasm and zeal which were later 
championed by the British Resident. With the pressure of both LMS and CMS missionaries, the government introduced several notifications and proclamations for the improvement of socio-economic and religious conditions of the oozhiyam servants of Kerala. The government issued a proclamation in 1829 that relieved the Christian converted people from doing bonded services on Sundays in the temples of the Hindus. In August 1864, the government issued a notification which exempted oozhiyam services to be delivered on the properties of tenants of government. According to another notification in 1885 , the oozhiyam servants were totally exempted from supplying provisions and vegetables, and from rendering bonded services to the uttupuras. Finally, in 1893, the oozhiyam system, one of the most baneful systems of caste slavery in Kerala, was abolished, although some remnants of it were still found. Finally, in 1905, the government issued a proclamation which permanently abolished the oozhyiam or bonded labor system in Kerala. It is therefore clear that the activities of the LMS and CMS missionaries contributed to the abolition of the oozhiyam system in Kerala. Their restless efforts helped the emancipation of the lowest sections of the society from their age-long bondage.

\section{References}

Agur, C.M. 1990. Church history of Travancore. New Delhi: Asian Educational Services.

Annual Report of the London Missionary Society. 1841. Thiruvananthapuram: London Missionary Society.

Balakrishnan, A. 2016. Oozhiyam and Viruthi in Travancore: Negotiating a Vile Social Space. PhD Thesis, Department of History, University of Kerala, Thiruvananthapuram.

Dubois, A.J.A. 1897. Hindu manners, customs and ceremonies. Oxford: Clarendon Press.

Greenidge, C.W.W. 1958. Slavery. London: George Allen.

Hacker, I.H. 1908. A hundred years in Travancore. London: H.R. Allenson.

Heller, S.C. 1969. Structured social inequality: A reader in comparative social stratification. New York: Macmillan.

Jeffrey, R. 1994. The decline of Nair dominance: Society and politics in Travancore, 1847-1908. New Delhi: Manohar Publishers. 
Johnson, P. 2008. Change and continuity among the Nadars of South Kerala: A socio-economic study. PhD thesis, Department of History, University of Kerala, Thiruvananthapuram.

Nagam Aiya, V. 1891. The Travancore state manual. Vol. 1. New Delhi: Asian Educational Services.

Kawashima, K. 2006. Missionaries and a Hindu state: Travancore 18581936. New Delhi: Oxford University Press.

Kooiman, D. 1984. Conversion and socio-cultural change: A case study of south Travancore. Journal of Kerala Studies 9, 1-4: 1-23.

Kumar, E. 2010. People's participation and evolution of legislature in Travancore (1888-1948) - a historical study. PhD thesis, Department of History, University of Kerala, Thiruvananthapuram.

Kusuman, K.K. 1973. Slavery in Travancore. Trivandrum: Kerala Historical Society.

Marx, K. [1847] 1955. The poverty of philosophy. Paris: Progress Publishers. Mateer, S. 1991a. The land of charity: A descriptive account of Travancore and its people. Reprint. New Delhi: Asian Educational Services.

Mateer, S. 1991b. Native life in Travancore. Reprint. New Delhi: Asian Educational Services.

Nair, S.R. 1998. Social consequences of agrarian change in Travancore 1912-1936. Trivandrum: University of Kerala Press.

Nisar, M. \& M. Kandasamy 2007. Ayyankali: A Dalit leader of organic protest. Calicut: Other Books.

Pillai, T.K.V. 1996. The Travancore state manual. Vol. 2. Trivandrum: Kerala Gazetteers Department.

Ponnu, R. 2000. Sri Vaikunda Swamigal and the struggle for social equality in South India. Madurai: Ram Publishers.

Proudhon, P.-J. [1847] 2015. The philosophy of poverty. Available at: https://www.amazon.com/Philosophy-Poverty-Large-

Print/dp/1514226871. (Accessed on 25 April 2020.)

Ramachandran, P. 1976. Abolition of Uliam and Viruthi in Travancore. Journal of Kerala Studies 3: 521-525.

Sanal Mohan, P. 2015. Modernity of slavery: Struggles against caste inequality in colonial Kerala. New Delhi: Oxford University Press.

Siddharth, K. 2014. Bonded labor - tackling the system of slavery in South Asia. New York: Columbia University Press. 
Varghese, T. 1986. A study of the impact of the church missionary society on the social and cultural history of Travancore and Cochin. Trivandrum: University of Kerala Press.

Varghese, T.C. 1970. Agrarian change and economic consequences: Land tenures in Kerala 1850-1960. Bombay: Allied Publishers.

Ward, B.S. \& P.E. Conner 1994. Memoir of the survey of the Travancore and Cochin States. Vol. 1. Reprint. Trivandrum: Kerala Gazetteers Department.

Yesudas, R.N. 1977. British policy in Travancore 1805-1849. Trivandrum: Kerala Historical Society.

Yesudas, R.N. 1980. History of the London Missionary Society in Travancore 1806-1808. Trivandrum: Kerala Historical Society.

Dr Ayyappan Balakrishnan Department of History University College Thiruvananthapuram

Kerala, India balakrishnana1000@gmail.com 